\title{
Explaining the model of comprehensive waste management in urban and rural areas and intermediate spaces (Case study: Khorasan Razavi province)
}

\section{Explicando el modelo de gestión integral de residuos en áreas urbanas y rurales y espacios intermedios (Estudio de caso: provincia de Khorasan Razavi)}

\author{
Sirus Shafaghi \\ Faculty member of Shakhes Pajouh Research Institute, Isfahan, Iran \\ ORCID: https://orcid.org/0000-0001-6496-6312

\section{Ramazan Ali Shurabi} \\ PhD Student in Geography and Urban Planning, Department of Geography, Shakhes Pajouh \\ Research Institute, Isfahan, Iran \\ ORCID: https://orcid.org/0000-0001-5313-4879
}

Received 09-08-20 Revised 10-10-20

*Correspondence

Email: shoorabiramezanali@yahoo.com
Accepted 20-12-21 On line 01-29-21

Cite as: 


\section{Summary}

One of the main topics of sustainable development is environmental issues. Waste management is one of the most important environmental programs in the world. Today, statesmen have come to the conclusion that in order to achieve an ideal and sustainable society, it is necessary to pay attention to waste management. This study was conducted to identify the current status of waste management in Khorasan Razavi province and provide an optimal management model. This is a descriptive-analytical study. The sample population includes all cities and villages of Khorasan Razavi province. The sample size in cities with waste management organization was in full and in other cities and districts using random sampling method using Cochran's formula. The results were classified and analyzed using SPSS, Excel and GIS software. Data collection tools were library resources, field resources including interviews with experts, managers and professors of technology. Preparation and completion of questionnaires from urban and rural areas is the preparation of checklists and field visits. Based on the SWOT model strategy and internal and external environment analysis, the most important strength is the reduction of entrepreneurship in the implementation of waste management activities and the lack of a comprehensive plan for waste management is the most important weakness. In assessing the external environment, the existence of industries and markets for the consumption of recycled materials in the province and the region is the most important opportunity and the existence of economic crises in urban and rural communities and industrial areas in the region is the most important threat. The results of the study indicate the need to improve the framework and infrastructure of waste management in the province and the development of laws and detailed monitoring systems to implement the findings and scientific and practical experiences of other countries to achieve economic, social and environmental goals.

Keywords: Waste Management, Environment, Sustainable Development, Khorasan Razavi

\section{Resumen}

Uno de los principales temas del desarrollo sostenible son las cuestiones ambientales. La gestión de residuos es uno de los programas medioambientales más importantes del mundo. Hoy, los estadistas han llegado a la conclusión de que para lograr una sociedad ideal y sostenible es necesario prestar atención a la gestión de residuos. Este estudio se realizó para identificar el estado actual de la gestión de residuos en la provincia de Khorasan Razavi y proporcionar un modelo de gestión óptimo. Este es un estudio descriptivo-analítico. La población de muestra incluye todas las ciudades y pueblos de la provincia de Khorasan Razavi. El tamaño de la muestra en las ciudades con organización de gestión de residuos fue completo y en otras ciudades y distritos utilizando el método de muestreo aleatorio utilizando la fórmula de Cochran. Los resultados se clasificaron y analizaron mediante los programas SPSS, Excel y GIS. Las herramientas de recopilación de datos fueron recursos bibliotecarios, recursos de campo, incluidas entrevistas con expertos, gerentes y profesores de tecnología. La preparación y llenado de cuestionarios de áreas urbanas y rurales es la preparación de listas de verificación y visitas de campo. Con base en la estrategia del modelo DAFO y el análisis del entorno interno y externo, la fortaleza más importante es la reducción del espíritu empresarial en la implementación de actividades de gestión de residuos y la falta de un plan integral para la gestión de residuos es la debilidad más importante. Al evaluar el entorno externo, la existencia de industrias y mercados para el consumo de materiales reciclados en la provincia y la región 
es la oportunidad más importante y la existencia de crisis económicas en las comunidades urbanas, rurales y áreas industriales de la región es la más importante. amenaza. Los resultados del estudio señalan la necesidad de mejorar el marco e infraestructura de la gestión de residuos en la provincia y el desarrollo de leyes y sistemas de monitoreo detallado para implementar los hallazgos y experiencias científicas y prácticas de otros países para lograr metas económicas, sociales y ambientales.

Palabras clave: Gestión de residuos, medio ambiente, desarrollo sostenible, Khorasan Razavi

\section{Introduction}

Today, waste management is one of the most essential pillars of sustainable development. In this regard, the law on waste management and the relevant executive regulations are a turning point that has been prepared and approved for related planning. In this law, waste management as one of the most important factors of implementation, responsible for planning, organizing, care, as well as executive operations of production, collection, storage, separation, transportation, recycling, processing, waste disposal and most importantly, education and information have been identified. Also, the executive management should prepare a comprehensive and detailed waste management plan in such a way that in formulating it, management measures such as reducing and minimizing the production of waste in the beginning, production of goods with more and easier recyclability, proper separation and collection, recovery and disposal of their principles (Abdoli, 2012).

Along with various problems and issues of cities and villages in Iran, environmental hazards caused by waste management is one of the main problems of the country. This issue, especially in Khorasan Razavi province, has become complex and wide-ranging due to major reasons such as high population density, the existence of many tourist attractions and special geographical location (Governor of Khorasan Razavi, 2016). This problem has not only affected most of the power of urban management and even the province, but also has jeopardized the process of sustainable and principled development. In 1992, about 2,000 tons of ordinary waste was produced daily in the metropolis of Mashhad and 1,162 tons in the cities of the province (Khorasan Razavi provincial Government Urban Affairs office Report).

Existence of diversity in the production wastes in the province according to the demographic situation and the industrial, agricultural and medical situation of the province, which can be said to contain almost all types of wastes in full and The vastness of the rural fabric in this province and the environmental view of the issues, prompts the researcher to look for a comprehensive and barrier model for the province's waste. Because at the moment, some of the wastes have no place in the planning of the officials and supervisors, and in the near future, its problems will affect everyone. Therefore, from the beginning of planning for waste management in the province, we must deal with the shortage of land in order to achieve the final result. An important point in this regard is to pay attention to the participation of the private sector in the implementation of the proposed projects. Because if there is a government view on the issue, we will still have the current problems.

Therefore, the purpose of this study is to examine the duties and powers of urban and rural management and. ... In terms of meeting existing needs and by organizing the scattered and 
regional activities to somehow review and deconstruct and propose laws and organizations appropriate to the current needs. This in turn requires that planning actions on the one hand and management actions on the other hand be considered as a single and integrated process and the interrelationships between them in the field of waste management be observed (Asadi, 2012). In this regard, the present study intends to review the law of waste management and its executive regulations and the constitution of the country and the situation of Khorasan Razavi province according to the geographical location of its cities and villages and intermediate centers, finally, provide a suitable model for comprehensive waste management at the regional level that can be generalized and implemented in different regions of the country.

The research method in this research is descriptive-analytical. This method includes two stages of documentary and library studies and field studies. The statistical population of the study includes the cities of Khorasan Razavi province in two groups of cities with more than 150,000 people and having a waste management organization and other cities of the province are the districts of Khorasan Razavi province, rural districts of Khorasan Razavi province and experts and managers in the field of waste management at the national, regional and local levels. The required statistics and information collected by statistical software such as SPSS and EXCEL are classified and analyzed.

\section{Theoretical foundations}

\section{Integrated waste management}

Integrated waste management means avoiding uncoordinated management for integrated waste management (IWM). Such a comprehensive and integrated approach extends the entire waste cycle to all urban-rural and intermediate areas, from beginning to end, including production avoidance, production reduction, storage, collection, transportation, recovery, recycling, and reuse., Waste treatment and landfill, manages with emphasis on environmental issues and sustainable development. In fact, integrated waste management is a framework for designing and implementing new waste management systems and for analyzing and optimizing existing systems. Integrated waste management means that all aspects of a waste management system (technical and non-technical) must be considered together because they are interconnected and developments in one area affect practices or activities in other areas (Www.unep.org).

The management should assess local needs and conditions and then select the most appropriate combination of waste management activities according to the existing conditions, including short-term and long-term plans (www.epa.go).

\section{Advantages of having an integrated waste management model}

Having a model for integrated waste management can have several benefits. If you have an integrated management model and implement it, the main benefits that can be expected from the proper implementation of integrated waste management are:

1. Regional identification of waste production areas and concentration and density of different types of waste

2. Creating a complete and comprehensive database for the province's waste

3. Planning for the transportation system in the province based on different regions 
4. Saving on infrastructure investments such as construction of landfills and temporary landfills

5. Prevention and reduction of environmental and health pollution

6. Planning for the construction of waste recycling industries according to the type of waste production and its distribution in the province

7. Possibility of transferring recycled materials from small towns and villages to recycling centers

8. Possibility of applying comprehensive waste management for areas outside urban and rural areas and suburbs

9. The possibility of attracting private sector capital and creating employment

10. Possibility of generating energy (electricity - heat) from waste

11. Possibility of creating tourism, commercial and practical sites related to waste

\section{Introducing the study area}

Waste management is a cross-sectoral goal at the provincial level, which, like its high levels at the national level, is pursued by various ministries and organizations with different approaches and strategies. Meanwhile, the environmental approach and reducing its challenges in the province has been a higher priority than other dimensions. This issue has become complex and wide-ranging, especially in Khorasan Razavi province, due to major reasons such as high population density, the existence of many tourist attractions and special geographical location, this problem has affected not only the major part of urban and political management power, but also the province as a whole, and has also endangered the process of sustainable and principled development (Khorasan Razavi provincial Government: 2015). In the field of solid waste management in the province, what has been the basis of the work so far is determining the task of each of the management components to collect and dispose of such materials. It seems that coherence and coordination in the management of solid waste in the province is a plan, this can be done well by the Ministry of Interior and the direct cooperation of the Environment Organization, the Ministry of Health, the Ministry of Agriculture, the Ministry of Industry and the country's universities. In this regard, the necessary strategies should be planned and implemented in 5 main sections according to the financial and technical facilities as well as the environmental conditions of the region (Qasemi, 2011).

\section{Methodology}

The present research is of the type of applied research.

The research method in this research is descriptive-analytical.

The statistical population is divided into the following groups:

*Cities of Khorasan Razavi province in two groups of cities with more than 150 thousand people and having waste management organization and other cities of the province.

*Districts of Khorasan Razavi Province.

*Villages of Khorasan Razavi Province 
*Experts and managers in the field of waste management at the national, regional and local levels.

To select the sample, multi-stage sampling method is used and the sample size is as follows:

- In the case of cities with waste organization, the cities of Mashhad-Neishabour-Sabzevar and Torbat-e Heydarieh are in full count.

- Cities without waste management organization (68 cities) by random sampling method using Cochran's formula with an error rate of $2 \%$

- For districts (there are 65 districts in 2014 in Khorasan Razavi province) by random sampling using Cochran's formula with an error rate of 2 \%

- The sample size for two cases (cities without waste management organization and districts) is 20 samples (10 samples of cities and 10 samples of districts).

- Determining the size of villages: Villages with more than 50 households in the province have rural areas. Villagers in rural villages are responsible for village waste management. Therefore, 55 villages with more than 50 households that have rural development (2097) by random sampling method using Cochran's formula with an error rate of $13 \%$ of the sample size are 55 villages.

- 20 samples have been selected for the community of experts and managers in a targeted manner. For the validity of the questionnaire, first a number of questionnaires will be prepared and completed as a pilot and the validity coefficient of the questionnaire will be determined through Cronbach's alpha. The required statistics and information collected by statistical software such as SPSS and EXCEL are classified and analyzed and if necessary, using ARCGIS software, the required maps are prepared and the information is reviewed and analyzed.

\section{Results}

\section{Identification of the main criteria with Delphi technique}

In this study, in the first place, 32 indicators were selected as the main criteria in the discussion of urban and rural waste management and the space between them in Khorasan Razavi province. Also, based on the strategy obtained from the SWOT model and analysis of internal (strengths and weaknesses) and external (opportunities and threats) points of the waste system, the sub-criteria of each parameter in accordance with the main factor under review and analysis are given in Table 1.

Table 1

Results of applying Delphi technique in terms of opportunities, threats, weaknesses and strengths of waste management system in Khorasan Razavi province

\begin{tabular}{|c|l|l|l|l|}
\hline symbol & Opportunities & $\begin{array}{l}\text { First } \\
\text { round }\end{array}$ & $\begin{array}{l}\text { The } \\
\text { second } \\
\text { round }\end{array}$ & Result \\
\hline
\end{tabular}




\begin{tabular}{|c|c|c|c|c|}
\hline O1 & $\begin{array}{l}\text { Existence of private sector companies and institutions in the } \\
\text { implementation of waste management programs }\end{array}$ & 7.30 & 7.40 & Confirmation \\
\hline & $\begin{array}{l}\text { Increasing the level of knowledge and awareness of mayors, district } \\
\text { heads and governors compared to the past }\end{array}$ & 7.20 & 6.60 & Decline \\
\hline \multirow[t]{2}{*}{$\mathrm{O} 2$} & $\begin{array}{l}\text { High level of cultural indicators and religious teachings of the } \\
\text { people of the region }\end{array}$ & 7.10 & 8.00 & Confirmation \\
\hline & $\begin{array}{l}\text { Holding national and international training workshops and } \\
\text { conferences on waste management in the province }\end{array}$ & 7.60 & 6.70 & Decline \\
\hline \multirow[t]{2}{*}{$\mathrm{O} 3$} & $\begin{array}{l}\text { Existence of industries and markets for the consumption of recycled } \\
\text { materials in the province and region }\end{array}$ & 8.10 & 7.90 & Confirmation \\
\hline & $\begin{array}{l}\text { Existence of private sector companies and institutions in the } \\
\text { implementation of waste management programs }\end{array}$ & 8.10 & 6.70 & Decline \\
\hline $\mathrm{O} 4$ & $\begin{array}{l}\text { National attention and determination to waste management in the } \\
\text { region }\end{array}$ & 7.40 & 8.50 & Confirmation \\
\hline O5 & Creating job opportunities and raising the level of job creation & 7.70 & 7.40 & Confirmation \\
\hline O6 & $\begin{array}{l}\text { Existence of universities and specialized human resources in the } \\
\text { region }\end{array}$ & 7.20 & 7.20 & Confirmation \\
\hline O7 & $\begin{array}{l}\text { Existence of environmental laws as a suitable tool to control the } \\
\text { waste management process }\end{array}$ & 8.10 & 8.50 & Confirmation \\
\hline O8 & Existence of new technologies in waste management & 6.3 & 7 & Confirmation \\
\hline 90 & $\begin{array}{l}\text { Existence of information opportunities and educational } \\
\text { advertisements through radio and television and newspapers }\end{array}$ & 7.10 & 7.30 & Confirmation \\
\hline symbol & Threats & $\begin{array}{l}\text { First } \\
\text { round }\end{array}$ & $\begin{array}{l}\text { The } \\
\text { second } \\
\text { round }\end{array}$ & Result \\
\hline T1 & $\begin{array}{l}\text { Inadequate physical environment conditions in the implementation } \\
\text { of waste management programs }\end{array}$ & 8.40 & 7.30 & Confirmation \\
\hline $\mathrm{T} 2$ & $\begin{array}{l}\text { Existence of economic crises in the body of urban and rural } \\
\text { communities and industrial areas in the region }\end{array}$ & 7.20 & 7.80 & Confirmation \\
\hline \multirow[t]{2}{*}{$\mathrm{T} 3$} & $\begin{array}{l}\text { Existence of weak cooperation of relevant local departments in } \\
\text { waste management training, especially in small towns and villages } \\
\text { in the province }\end{array}$ & 7.7 & 7.3 & Confirmation \\
\hline & Lack of attention of villagers to waste management training & 7.9 & 6.5 & Decline \\
\hline T4 & $\begin{array}{l}\text { Existence of weak cooperation of governmental and non- } \\
\text { governmental organizations and bodies in waste management affairs }\end{array}$ & 8.20 & 8.10 & Confirmation \\
\hline \multirow[t]{2}{*}{ T5 } & $\begin{array}{l}\text { Slight changes in waste generation due to the presence of pilgrims, } \\
\text { tourists and seasonal tourists }\end{array}$ & 7.50 & 7.70 & Confirmation \\
\hline & $\begin{array}{l}\text { Lack of favorable cooperation of villagers in waste management } \\
\text { costs }\end{array}$ & 7.20 & 6.60 & Decline \\
\hline \multirow[t]{2}{*}{ T6 } & Dispersion of decision centers in waste management & 7.10 & 7.60 & Confirmation \\
\hline & $\begin{array}{l}\text { Lack of favorable cooperation of citizens in waste management } \\
\text { costs }\end{array}$ & 7.80 & 6.00 & Decline \\
\hline T7 & Lack of executive instructions regarding activities related to waste & 8.10 & 8.50 & Confirmation \\
\hline
\end{tabular}




\begin{tabular}{|c|c|c|c|c|}
\hline & management & & & \\
\hline $\mathrm{T} 8$ & Atmospheric conditions in different seasons of the year & 8.10 & 7.90 & Confirmation \\
\hline \multirow[t]{2}{*}{ symbol } & Strengths & $\begin{array}{l}\text { First } \\
\text { round }\end{array}$ & $\begin{array}{l}\text { The } \\
\text { second } \\
\text { round }\end{array}$ & Result \\
\hline & $\begin{array}{l}\text { Perform periodic evaluation and measurement of satisfaction with } \\
\text { the company's services }\end{array}$ & 7.70 & 6.00 & Decline \\
\hline S1 & Quality and type of compounds in waste tissue & 7.10 & 8.10 & Confirmation \\
\hline S2 & $\begin{array}{l}\text { Commencement of application of segregation strategy in storage } \\
\text { management and waste collection in the province }\end{array}$ & 7.80 & 8.70 & Confirmation \\
\hline \multirow[t]{2}{*}{ S3 } & $\begin{array}{l}\text { Reducing entrepreneurship in the implementation of waste } \\
\text { management activities }\end{array}$ & 7.60 & 8.15 & Confirmation \\
\hline & $\begin{array}{l}\text { Involve employees in the organization's training by forming } \\
\text { participation groups and idea banks }\end{array}$ & 8.00 & 6.20 & Decline \\
\hline S4 & $\begin{array}{l}\text { Serious determination of municipalities, villages and industries to } \\
\text { solve waste problems and cooperate with other bodies in this field }\end{array}$ & 8.10 & 7.40 & Confirmation \\
\hline \multirow[t]{2}{*}{ S5 } & $\begin{array}{l}\text { Establishment of waste management organization in Mashhad } \\
\text { metropolis and waste management office in some municipalities }\end{array}$ & 7.10 & 7.40 & Confirmation \\
\hline & Establishment of employee performance appraisal system & 7.30 & 6.80 & Decline \\
\hline S6 & $\begin{array}{l}\text { Existence of short-term and long-term executive plans in the field of } \\
\text { waste management in the province }\end{array}$ & 7.50 & 7.80 & Confirmation \\
\hline \multirow[t]{3}{*}{ S7 } & Prepare timely reports and financial statements & 7.50 & 7.20 & Confirmation \\
\hline & $\begin{array}{l}\text { Existence of private sector contractors in waste management in the } \\
\text { province }\end{array}$ & 7.60 & 6.50 & Decline \\
\hline & $\begin{array}{l}\text { Holding regular meetings of the provincial waste management } \\
\text { working group }\end{array}$ & 7.60 & 5.90 & Decline \\
\hline symbol & weak points & $\begin{array}{l}\text { First } \\
\text { round }\end{array}$ & $\begin{array}{l}\text { The } \\
\text { second } \\
\text { round }\end{array}$ & Result \\
\hline \multirow[t]{2}{*}{ W1 } & Lack of a comprehensive plan for waste management & $\div \div$ & 7.80 & Confirmation \\
\hline & Weakness in strategic and long-term thinking in managers & 8.40 & 7.80 & Decline \\
\hline W2 & Officials neglect waste management & 8.10 & 8.20 & Confirmation \\
\hline W3 & $\begin{array}{l}\text { Use of non-mechanized machines in waste collection and } \\
\text { transportation }\end{array}$ & 8.70 & 7.50 & Confirmation \\
\hline W4 & Lack of research and development & 7.70 & 7.20 & Confirmation \\
\hline W5 & Increasing and uncontrolled production of various types of waste & 7.70 & 7.50 & Confirmation \\
\hline W6 & $\begin{array}{l}\text { Lack of a comprehensive waste management database in the } \\
\text { province }\end{array}$ & 8.40 & 7.70 & Confirmation \\
\hline
\end{tabular}




\begin{tabular}{|c|c|c|c|c|}
\hline W7 & $\begin{array}{l}\text { Lack of use and application of new technologies, facilities and } \\
\text { facilities in the collection, transfer and processing and disposal of } \\
\text { waste }\end{array}$ & 8.30 & 6.70 & Confirmation \\
\hline W8 & Costly waste management & 8.20 & 7.63 & Confirmation \\
\hline \multirow[t]{4}{*}{ W9 } & $\begin{array}{l}\text { Low level of social awareness and limited social participation in } \\
\text { waste management }\end{array}$ & 8.10 & 7.90 & Confirmation \\
\hline & A large number of villages in the province & 8.60 & 5.90 & Decline \\
\hline & Island action of local managers in waste management & 7.20 & 6.50 & Decline \\
\hline & Weakness in promoting work culture & 7.50 & 6.90 & Decline \\
\hline
\end{tabular}

Then, in order to measure the degree of unity of opinion among the views presented by the elites, Kendall coefficient was used. Kendall coefficient in the first round was 0.345 and in the second round of Delphi technique was 0.629, which indicates a good consensus among experts. Also, a significant value of 0.001 has been obtained, which shows that the results can be relied on with $95 \%$ confidence. Also, the average score of all items is about 7, which indicates that the views are close. Therefore, the Delphi technique has been stopped and the identified indicators have been used for the final analysis.

\section{The final priority of the indicators with AHP technique}

After calculating the weight of the elements of each cluster, the final priority of the Swat matrix indices can be calculated. The weight obtained by comparing internal and external factors (W1) in the weight of their related elements (W2) will give the final weight of opportunities, threats, strengths and weaknesses. The final weight of opportunities, threats, strengths and weaknesses will be multiplied by the weight of the elements of each cluster, and finally the final priority of each indicator will be calculated. Determining the final priority of SWAT matrix indices with AHP technique is given in the table below (No. 2).

Table 2

\section{Determining the final priority of SWAT matrix indices using AHP technique}

\begin{tabular}{|c|c|c|c|c|c|c|c|c|}
\hline \multicolumn{2}{|c|}{$\begin{array}{l}\text { main } \\
\text { factors }\end{array}$} & \multicolumn{2}{|c|}{ Criteria } & $\begin{array}{l}\text { Agent in the } \\
\text { Criteria }\end{array}$ & $\begin{array}{l}\text { symb } \\
\text { ol }\end{array}$ & $\begin{array}{l}\text { Initial } \\
\text { weight }\end{array}$ & $\begin{array}{l}\text { Final } \\
\text { weight }\end{array}$ & $\begin{array}{l}\operatorname{Ran} \\
\mathrm{k}\end{array}$ \\
\hline \multirow{5}{*}{ 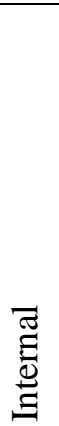 } & \multirow{5}{*}{ ñ } & \multirow{5}{*}{$\begin{array}{l}0.29 \\
4\end{array}$} & \multirow{5}{*}{$\begin{array}{l}0.62 \\
3\end{array}$} & 0.163 & S1 & 0.163 & 0,0283 & 21 \\
\hline & & & & 0.195 & S2 & 0.195 & 0.0338 & 11 \\
\hline & & & & 0.177 & S3 & 0.177 & 0.0308 & 14 \\
\hline & & & & 0.178 & S4 & 0.178 & 0.0309 & 13 \\
\hline & & & & 0.166 & S5 & 0.166 & 0.0289 & 20 \\
\hline
\end{tabular}




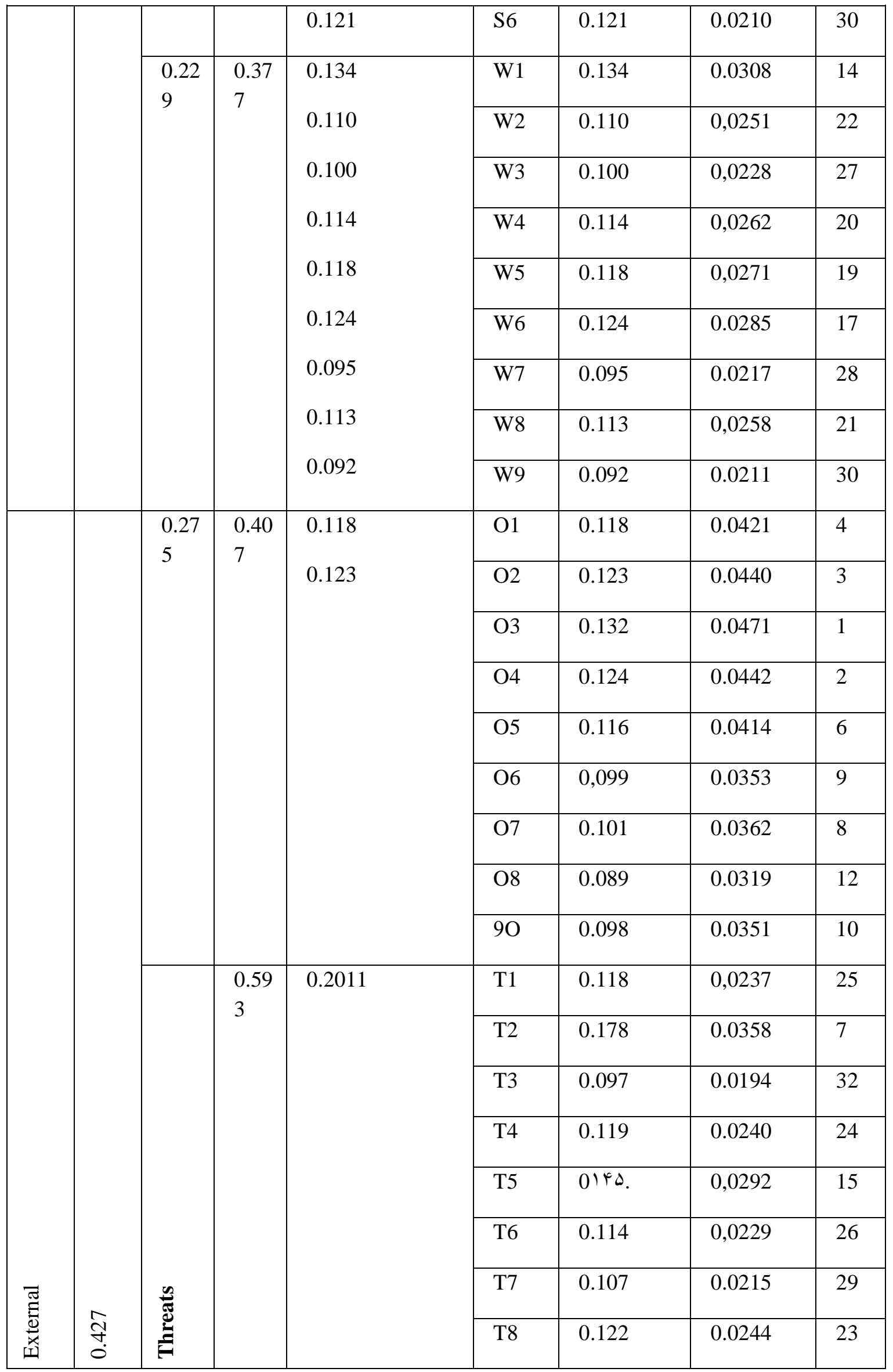




\section{Creating an evaluation matrix of internal and external factors}

To prepare the Internal Factors Evaluation Matrix (IFE), the weight coefficient of each factor is entered using the AHP technique. It should be noted that the weight of each criterion is also normalized in each cluster (internal-external). Also, the current status score of each factor from the perspective of the strategic management team is listed. To determine the final score of each factor, the coefficient of each factor is multiplied by its score and the sum of the final scores of each factor is calculated to determine the final score. The results of the cases described are shown in Tables 3 and 4.

Table 3

\section{Internal factors evaluation matrix (strengths and weaknesses)}

\begin{tabular}{|c|c|c|c|c|}
\hline $\begin{array}{l}\text { inter } \\
\text { nal } \\
\text { facto } \\
\text { rs }\end{array}$ & Subcriteria & $\begin{array}{l}\vec{E} \\
\overrightarrow{000} \\
\overrightarrow{0}\end{array}$ & 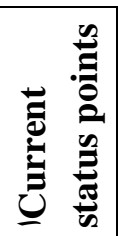 & 焉 \\
\hline \multirow[t]{6}{*}{$\begin{array}{l}\text { Stre } \\
\text { ngth } \\
\text { S }\end{array}$} & $\begin{array}{l}\text { Establishment of waste management organization in } \\
\text { Mashhad metropolis and waste management office in some } \\
\text { municipalities in the province }\end{array}$ & $\begin{array}{l}0.070 \\
3\end{array}$ & 3.44 & $\begin{array}{l}0.24 \\
2\end{array}$ \\
\hline & $\begin{array}{l}\text { Reducing entrepreneurship in the implementation of waste } \\
\text { management activities }\end{array}$ & $\begin{array}{l}0.083 \\
9\end{array}$ & 2.96 & $\begin{array}{l}0.24 \\
8\end{array}$ \\
\hline & $\begin{array}{l}\text { Commencement of application of segregation strategy in } \\
\text { storage management and waste collection in the province }\end{array}$ & $\begin{array}{l}0.076 \\
5\end{array}$ & 4 & $\begin{array}{l}0.30 \\
6\end{array}$ \\
\hline & $\begin{array}{l}\text { Serious determination of municipalities, villages and } \\
\text { industries to solve waste problems and cooperate with } \\
\text { other bodies in this field }\end{array}$ & $\begin{array}{l}0.076 \\
7\end{array}$ & 3.68 & $\begin{array}{l}0.28 \\
2\end{array}$ \\
\hline & Quality and type of compounds in waste tissue & $\begin{array}{l}0.071 \\
7\end{array}$ & 3.44 & $\begin{array}{l}0.24 \\
7\end{array}$ \\
\hline & $\begin{array}{l}\text { Existence of short-term and long-term executive plans in } \\
\text { the field of waste management in the province }\end{array}$ & $\begin{array}{l}0.052 \\
2\end{array}$ & $\begin{array}{l}0.16 \\
7\end{array}$ & $\begin{array}{l}0.16 \\
7\end{array}$ \\
\hline \multirow{4}{*}{$\begin{array}{l}\text { wea } \\
k \\
\text { poin } \\
\text { ts }\end{array}$} & Lack of a comprehensive plan for waste management & $\begin{array}{l}0.029 \\
0\end{array}$ & $\begin{array}{l}0.24 \\
4\end{array}$ & $\begin{array}{l}0.24 \\
4\end{array}$ \\
\hline & $\begin{array}{l}\text { Lack of use and application of new technologies, facilities } \\
\text { and facilities in the collection, transfer and processing and } \\
\text { disposal of waste }\end{array}$ & $\begin{array}{l}0,023 \\
7\end{array}$ & $\begin{array}{l}0.20 \\
5\end{array}$ & $\begin{array}{l}0.20 \\
5\end{array}$ \\
\hline & $\begin{array}{l}\text { Use of non-mechanized machines in waste collection and } \\
\text { transportation }\end{array}$ & $\begin{array}{l}0.021 \\
5\end{array}$ & $\begin{array}{l}0.20 \\
4\end{array}$ & $\begin{array}{l}0.20 \\
4\end{array}$ \\
\hline & Low level of social awareness and limited social & 0,024 & 0.23 & 0.23 \\
\hline
\end{tabular}


Explaining the model of comprehensive waste management in urban and rural areas and intermediate spaces (Case study: Khorasan Razavi province).

\begin{tabular}{|c|c|c|c|c|}
\hline & participation in waste management & 7 & 9 & 9 \\
\hline & $\begin{array}{l}\text { Lack of a comprehensive waste management database in } \\
\text { the province }\end{array}$ & $\begin{array}{l}0.025 \\
5\end{array}$ & $\begin{array}{l}0.19 \\
99\end{array}$ & $\begin{array}{l}0.19 \\
99\end{array}$ \\
\hline & Lack of research and development & $\begin{array}{l}0,026 \\
9\end{array}$ & $\begin{array}{l}0.23 \\
8\end{array}$ & $\begin{array}{l}0.23 \\
8\end{array}$ \\
\hline & $\begin{array}{l}\text { Increasing and uncontrolled production of various types of } \\
\text { waste }\end{array}$ & $\begin{array}{l}0,020 \\
5\end{array}$ & $\begin{array}{l}0.20 \\
3\end{array}$ & $\begin{array}{l}0.20 \\
3\end{array}$ \\
\hline & Officials neglect waste management & $\begin{array}{l}0.024 \\
3\end{array}$ & $\begin{array}{l}0.20 \\
5\end{array}$ & $\begin{array}{l}0.20 \\
5\end{array}$ \\
\hline & Costly waste management & $\begin{array}{l}0,019 \\
9\end{array}$ & $\begin{array}{l}0.15 \\
1\end{array}$ & $\begin{array}{l}0.15 \\
1\end{array}$ \\
\hline Total & & 1.000 & - & $\begin{array}{l}3.37 \\
9\end{array}$ \\
\hline
\end{tabular}

Table 4

External factors evaluation matrix (threats and opportunities)

\begin{tabular}{|c|c|c|c|c|}
\hline$\frac{\overrightarrow{2}}{e_{0}^{2}} \cong$ & Subcriteria & $\sum^{\frac{.00}{0}}=$ & 焉 & 氖 \\
\hline \multirow{8}{*}{ 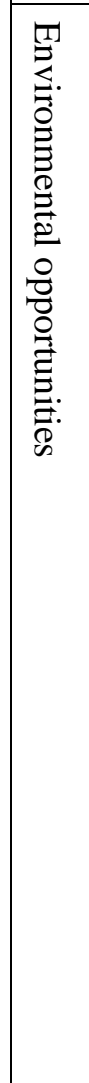 } & $\begin{array}{l}\text { Existence of private sector companies and institutions in the } \\
\text { implementation of waste management programs }\end{array}$ & 0.0421 & 3.6 & $\begin{array}{l}0.15 \\
2\end{array}$ \\
\hline & $\begin{array}{l}\text { High level of cultural indicators and religious teachings of the } \\
\text { people of the region }\end{array}$ & 0.0440 & $\begin{array}{l}3.4 \\
4\end{array}$ & $\begin{array}{l}0.15 \\
1\end{array}$ \\
\hline & $\begin{array}{l}\text { Existence of industries and markets for the consumption of } \\
\text { recycled materials in the province and region }\end{array}$ & 0.0471 & $\begin{array}{l}3.8 \\
4\end{array}$ & $\begin{array}{l}0.18 \\
1\end{array}$ \\
\hline & $\begin{array}{l}\text { National attention and determination to waste management in } \\
\text { the region }\end{array}$ & 0.0442 & 4 & $\begin{array}{l}0.17 \\
7\end{array}$ \\
\hline & Creating job opportunities and raising the level of employment & 0.0414 & 4 & $\begin{array}{l}0.16 \\
6\end{array}$ \\
\hline & $\begin{array}{l}\text { Existence of universities and specialized human resources in the } \\
\text { region }\end{array}$ & 0.0353 & 4 & $\begin{array}{l}0.14 \\
1\end{array}$ \\
\hline & $\begin{array}{l}\text { Existence of environmental laws as a suitable tool to control the } \\
\text { waste management process }\end{array}$ & 0.0362 & $\begin{array}{l}3.4 \\
4\end{array}$ & $\begin{array}{l}0.12 \\
5\end{array}$ \\
\hline & $\begin{array}{l}\text { Existence of opportunities for information and educational } \\
\text { advertisements through radio and television and newspapers }\end{array}$ & 0.0319 & 4 & $\begin{array}{l}0.12 \\
8\end{array}$ \\
\hline
\end{tabular}




\begin{tabular}{|c|c|c|c|c|}
\hline & Existence of new technologies in waste management & 0.0351 & 2 & $\begin{array}{l}0,07 \\
0\end{array}$ \\
\hline \multirow{8}{*}{ 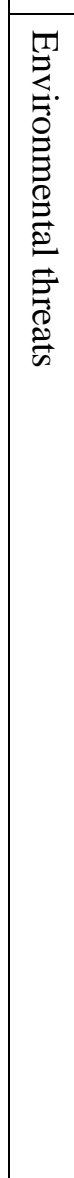 } & $\begin{array}{l}\text { Inadequate physical environment conditions in the } \\
\text { implementation of waste management programs }\end{array}$ & 0,0237 & 3.6 & $\begin{array}{l}0.08 \\
5\end{array}$ \\
\hline & $\begin{array}{l}\text { Existence of economic crises in the body of urban and rural } \\
\text { communities and industrial areas in the region }\end{array}$ & 0.0788 & 3.2 & $\begin{array}{l}0.25 \\
2\end{array}$ \\
\hline & $\begin{array}{l}\text { Existence of weak cooperation of governmental and non- } \\
\text { governmental organizations and bodies in waste management } \\
\text { affairs }\end{array}$ & 0.0843 & 4 & $\begin{array}{l}0.29 \\
7\end{array}$ \\
\hline & $\begin{array}{l}\text { Slight changes in waste generation due to the presence of } \\
\text { pilgrims, tourists and seasonal tourists }\end{array}$ & 0.0792 & $\begin{array}{l}3.4 \\
4\end{array}$ & $\begin{array}{l}0.21 \\
7\end{array}$ \\
\hline & Dispersal of decision centers in waste management & 0.0741 & $\begin{array}{l}3.2 \\
8\end{array}$ & $\begin{array}{l}0.21 \\
3\end{array}$ \\
\hline & $\begin{array}{l}\text { Existence of weak cooperation of relevant local departments in } \\
\text { waste management training, especially in small towns and } \\
\text { villages in the province }\end{array}$ & 0.0632 & $\begin{array}{l}0.1 \\
88\end{array}$ & $\begin{array}{l}0.18 \\
8\end{array}$ \\
\hline & $\begin{array}{l}\text { Lack of executive instructions regarding activities related to } \\
\text { waste management }\end{array}$ & 0.0649 & $\begin{array}{l}2.6 \\
48\end{array}$ & $\begin{array}{l}2.64 \\
8\end{array}$ \\
\hline & Atmospheric conditions in different seasons of the year & 0.0572 & $\begin{array}{l}0.0 \\
00\end{array}$ & $\begin{array}{l}0.00 \\
0\end{array}$ \\
\hline & & 1.000 & - & $\begin{array}{l}2,54 \\
2\end{array}$ \\
\hline
\end{tabular}

The results obtained from the internal and external factor evaluation matrix indicate that in general, strengths outweigh weaknesses. At the same time, if opportunities are seized, threats can be overcome and weaknesses eliminated. As a result, SO strategies are a top priority.

\section{Forming a quantitative matrix of strategic planning}

According to the evaluation matrix of internal and external factors, the strategies that should be considered are the strategies of using the strengths of the organization to take advantage of opportunities. In addition, in order to quantitatively analyze the dimensions of waste management planning in a strategic approach in the context of identifying the attractiveness of each of the four strategies, it is necessary to analyze the dimensions of each indicator in contrast to other elements. Therefore, with the formation of the Quantitative Strategic Planning Matrix (QSPM), the existing four strategies are prioritized. Based on the Strategic Planning Quantitative Matrix Analysis (QSPM), the priority for selecting strategies is as follows:

1- Strategies based on strength-opportunity (offensive) or SO with a score of 4.994.

2- Weak-Opportunity-Based Strategies or WO with a score of 2.760. 
3- Strategies based on strength-threat or ST with a score of 1.575.

4- Threat-based (defensive) or WT based strategies with a score of 3.372.

\section{Strategies studied}

SO1: Increase private sector participation in order to implement long-term waste management plans.

SO2: Development of segregation programs from the source and acceleration of its implementation to supply raw materials for recycling industries.

SO3: Development of recycling industries in the province and creating a competitive environment between existing recycling industries and thus increasing the quality of isolated materials.

SO4: Increase the level of participation of managers and municipal responsibility in implementing waste management processes.

ST1: Implement a comprehensive and integrated waste management system in the urban complex and reduce parallel activities to increase systematic productivity and reduce waste management costs.

ST2: Increase cooperation and coordination between departments in public awareness and education at the local level.

WO1: This strategy is the best scenario for implementing a weakness-opportunity strategy.

WO2: The teaching and research capacity of universities in the region to provide specialized manpower and research needs in the waste management process.

WT1: Application of new technologies in waste management due to poor physical environment and lack of funding.

WT2: Creating sustainable and accessible resources to meet the costs and credits required by waste management.

WT3: Establish a comprehensive waste management database to address long-term and shortterm waste management issues.

WT4: Raising the level of public awareness of managers and officials of relevant government and non-government agencies in the implementation of the waste management processs.

WT5: Preparation of executive instructions (rules and guidelines) for waste management in the design, construction, operation and monitoring of the waste management system in accordance with the physical, social, environmental and economic conditions. 
Table 5

Quantitative Strategic Planning Matrix (QSPM)

\begin{tabular}{|c|c|c|c|c|c|c|c|c|c|}
\hline \multirow[b]{2}{*}{ SWOT } & \multirow{2}{*}{$\begin{array}{l}\text { Weig } \\
\text { hted } \\
\text { points }\end{array}$} & \multicolumn{2}{|c|}{ SO } & \multicolumn{2}{|c|}{ ST } & \multicolumn{2}{|c|}{ WO } & \multicolumn{2}{|c|}{ WT } \\
\hline & & $\begin{array}{l}\text { A } \\
\text { S }\end{array}$ & $\mathrm{TS}$ & $\begin{array}{l}\text { A } \\
S\end{array}$ & TS & AS & TS & AS & TS \\
\hline $\begin{array}{l}\text { Lack of a comprehensive plan for waste } \\
\text { management }\end{array}$ & $\begin{array}{l}0,028 \\
3\end{array}$ & 2 & $\begin{array}{l}0.08 \\
4\end{array}$ & 3 & $\begin{array}{l}0.12 \\
6\end{array}$ & 1 & $\begin{array}{l}0.04 \\
2\end{array}$ & 4 & 0.113 \\
\hline $\begin{array}{l}\text { Lack of use and application of new } \\
\text { technologies, facilities and facilities in } \\
\text { the collection, transfer and processing } \\
\text { and disposal of waste }\end{array}$ & $\begin{array}{l}0.033 \\
8\end{array}$ & 4 & $\begin{array}{l}0.17 \\
6\end{array}$ & 2 & $\begin{array}{l}0.08 \\
8\end{array}$ & 1 & $\begin{array}{l}0.04 \\
4\end{array}$ & 2 & 0.068 \\
\hline $\begin{array}{l}\text { Use of non-mechanized machines in } \\
\text { waste collection and transportation }\end{array}$ & $\begin{array}{l}0.030 \\
8\end{array}$ & 2 & $\begin{array}{l}0.09 \\
4\end{array}$ & 4 & $\begin{array}{l}0.18 \\
8\end{array}$ & 1 & $\begin{array}{l}0.04 \\
7\end{array}$ & 4 & 0.123 \\
\hline $\begin{array}{l}\text { Low level of social awareness and } \\
\text { limited social participation in waste } \\
\text { management }\end{array}$ & $\begin{array}{l}0.030 \\
9\end{array}$ & 3 & $\begin{array}{l}0.13 \\
3\end{array}$ & 4 & $\begin{array}{l}0.17 \\
7\end{array}$ & 2 & $\begin{array}{l}0.08 \\
8\end{array}$ & 2 & 0.062 \\
\hline $\begin{array}{l}\text { Lack of a comprehensive waste } \\
\text { management database in the province }\end{array}$ & $\begin{array}{l}0.028 \\
9\end{array}$ & 3 & $\begin{array}{l}0.12 \\
4\end{array}$ & 3 & $\begin{array}{l}0.12 \\
4\end{array}$ & 1 & $\begin{array}{l}0.04 \\
1\end{array}$ & 4 & 0.115 \\
\hline Lack of research and development & $\begin{array}{l}0.021 \\
0\end{array}$ & 2 & $\begin{array}{l}0.07 \\
1\end{array}$ & 3 & $\begin{array}{l}0.10 \\
6\end{array}$ & 3 & $\begin{array}{l}0.10 \\
6\end{array}$ & 4 & 0.084 \\
\hline $\begin{array}{l}\text { Establishment of waste management } \\
\text { organization in Mashhad metropolis and } \\
\text { waste management office in some } \\
\text { municipalities in the province }\end{array}$ & $\begin{array}{l}0.030 \\
8\end{array}$ & 3 & $\begin{array}{l}0.10 \\
9\end{array}$ & 1 & $\begin{array}{l}0.03 \\
6\end{array}$ & 3 & $\begin{array}{l}0.10 \\
9\end{array}$ & 2 & 0.062 \\
\hline $\begin{array}{l}\text { Reducing entrepreneurship in the } \\
\text { implementation of waste management } \\
\text { activities }\end{array}$ & $\begin{array}{l}0,025 \\
1\end{array}$ & 3 & $\begin{array}{l}0.09 \\
6\end{array}$ & 2 & $\begin{array}{l}0.06 \\
4\end{array}$ & 1 & $\begin{array}{l}0.03 \\
2\end{array}$ & 2 & 0.050 \\
\hline $\begin{array}{l}\text { Commencement of application of } \\
\text { segregation strategy in storage } \\
\text { management and waste collection in the } \\
\text { province }\end{array}$ & $\begin{array}{l}0,022 \\
8\end{array}$ & 3 & $\begin{array}{l}0.10 \\
5\end{array}$ & 4 & $\begin{array}{l}0.14 \\
0\end{array}$ & 1 & $\begin{array}{l}0.03 \\
5\end{array}$ & 4 & 0.091 \\
\hline $\begin{array}{l}\text { Serious determination of municipalities, } \\
\text { villages and industries to solve waste } \\
\text { problems and cooperate with other } \\
\text { bodies in this field }\end{array}$ & $\begin{array}{l}0,026 \\
2\end{array}$ & 4 & $\begin{array}{l}0.11 \\
6\end{array}$ & 3 & $\begin{array}{l}0.08 \\
7\end{array}$ & 2 & $\begin{array}{l}0.05 \\
8\end{array}$ & 3 & 0.078 \\
\hline $\begin{array}{l}\text { Quality and type of compounds in waste } \\
\text { tissue }\end{array}$ & $\begin{array}{l}0,027 \\
1\end{array}$ & 2 & $\begin{array}{l}0.04 \\
7\end{array}$ & 4 & $\begin{array}{l}0.09 \\
5\end{array}$ & 2 & $\begin{array}{l}0.04 \\
7\end{array}$ & 3 & 0.081 \\
\hline
\end{tabular}




\begin{tabular}{|c|c|c|c|c|c|c|c|c|c|}
\hline \multirow{2}{*}{ SWOT } & \multirow{2}{*}{$\begin{array}{l}\text { Weig } \\
\text { hted } \\
\text { points }\end{array}$} & \multicolumn{2}{|c|}{ SO } & \multicolumn{2}{|c|}{ ST } & \multicolumn{2}{|c|}{ WO } & \multicolumn{2}{|l|}{ WT } \\
\hline & & $\begin{array}{l}\text { A } \\
S\end{array}$ & TS & $\begin{array}{l}\text { A } \\
\text { S }\end{array}$ & TS & AS & $\mathrm{TS}$ & AS & TS \\
\hline $\begin{array}{l}\text { Existence of short-term and long-term } \\
\text { executive plans in the field of waste } \\
\text { management in the province }\end{array}$ & $\begin{array}{l}0.028 \\
5\end{array}$ & 4 & $\begin{array}{l}0.08 \\
6\end{array}$ & 1 & $\begin{array}{l}0,02 \\
2\end{array}$ & 3 & $\begin{array}{l}0.06 \\
5\end{array}$ & 4 & 0.114 \\
\hline $\begin{array}{l}\text { Existence of private sector companies } \\
\text { and institutions in the implementation of } \\
\text { waste management programs }\end{array}$ & $\begin{array}{l}0.021 \\
7\end{array}$ & 4 & $\begin{array}{l}0,09 \\
9\end{array}$ & 2 & $\begin{array}{l}0.04 \\
9\end{array}$ & 3 & $\begin{array}{l}0.07 \\
4\end{array}$ & 5 & 0.108 \\
\hline $\begin{array}{l}\text { High level of cultural indicators and } \\
\text { religious teachings of the people of the } \\
\text { region }\end{array}$ & $\begin{array}{l}0,025 \\
8\end{array}$ & 1 & $\begin{array}{l}0.02 \\
6\end{array}$ & 4 & $\begin{array}{l}0.10 \\
2\end{array}$ & 3 & $\begin{array}{l}0.07 \\
7\end{array}$ & 4 & 0.103 \\
\hline $\begin{array}{l}\text { Existence of industries and markets for } \\
\text { the consumption of recycled materials in } \\
\text { the province and region }\end{array}$ & $\begin{array}{l}0.021 \\
1\end{array}$ & 4 & $\begin{array}{l}0.10 \\
7\end{array}$ & 4 & $\begin{array}{l}0.10 \\
7\end{array}$ & 1 & $\begin{array}{l}0.02 \\
7\end{array}$ & 4 & 0.085 \\
\hline $\begin{array}{l}\text { Existence of private sector companies } \\
\text { and institutions in the implementation of } \\
\text { waste management programs }\end{array}$ & $\begin{array}{l}0.042 \\
1\end{array}$ & 3 & $\begin{array}{l}0.06 \\
1\end{array}$ & 4 & $\begin{array}{l}0.08 \\
2\end{array}$ & 2 & $\begin{array}{l}0.04 \\
1\end{array}$ & 4 & 0.169 \\
\hline $\begin{array}{l}\text { High level of cultural indicators and } \\
\text { religious teachings of the people of the } \\
\text { region }\end{array}$ & $\begin{array}{l}0.044 \\
0\end{array}$ & 2 & $\begin{array}{l}0.04 \\
9\end{array}$ & 4 & $\begin{array}{l}0.09 \\
7\end{array}$ & 1 & $\begin{array}{l}0.02 \\
4\end{array}$ & 5 & 0.220 \\
\hline $\begin{array}{l}\text { Existence of industries and markets for } \\
\text { the consumption of recycled materials in } \\
\text { the province and region }\end{array}$ & $\begin{array}{l}0.047 \\
1\end{array}$ & 2 & $\begin{array}{l}0.04 \\
0\end{array}$ & 4 & $\begin{array}{l}0.08 \\
0\end{array}$ & 1 & $\begin{array}{l}0,02 \\
0\end{array}$ & 5 & 0.235 \\
\hline $\begin{array}{l}\text { National attention and determination to } \\
\text { waste management in the region }\end{array}$ & $\begin{array}{l}0.044 \\
2\end{array}$ & 1 & $\begin{array}{l}0.03 \\
5\end{array}$ & 4 & $\begin{array}{l}0.14 \\
0\end{array}$ & 4 & $\begin{array}{l}0.14 \\
0\end{array}$ & 4 & 0.177 \\
\hline $\begin{array}{l}\text { Creating job opportunities and raising the } \\
\text { level of employment }\end{array}$ & $\begin{array}{l}0.041 \\
4\end{array}$ & 3 & $\begin{array}{l}0.12 \\
6\end{array}$ & 2 & $\begin{array}{l}0.08 \\
4\end{array}$ & 2 & $\begin{array}{l}0.08 \\
4\end{array}$ & 3 & 0.124 \\
\hline $\begin{array}{l}\text { Existence of universities and specialized } \\
\text { human resources in the region }\end{array}$ & $\begin{array}{l}0.035 \\
3\end{array}$ & 3 & $\begin{array}{l}0.11 \\
1\end{array}$ & 3 & $\begin{array}{l}0.11 \\
1\end{array}$ & 1 & $\begin{array}{l}0.03 \\
7\end{array}$ & 4 & 0.141 \\
\hline $\begin{array}{l}\text { Existence of information opportunities } \\
\text { and educational advertisements through } \\
\text { radio and television and newspapers }\end{array}$ & $\begin{array}{l}0.036 \\
2\end{array}$ & 3 & $\begin{array}{l}0.11 \\
9\end{array}$ & 3 & $\begin{array}{l}0.11 \\
9\end{array}$ & 1 & $\begin{array}{l}0.04 \\
0\end{array}$ & 4 & 0.145 \\
\hline $\begin{array}{l}\text { Existence of new technologies in waste } \\
\text { management }\end{array}$ & $\begin{array}{l}0.031 \\
9\end{array}$ & 2 & $\begin{array}{l}0.07 \\
2\end{array}$ & 4 & $\begin{array}{l}0.14 \\
3\end{array}$ & 2 & $\begin{array}{l}0.07 \\
2\end{array}$ & 5 & 0.160 \\
\hline $\begin{array}{l}\text { Inadequate physical environment } \\
\text { conditions in the implementation of } \\
\text { waste management programs }\end{array}$ & $\begin{array}{l}0.035 \\
1\end{array}$ & 1 & $\begin{array}{l}0.03 \\
2\end{array}$ & 3 & $\begin{array}{l}0.09 \\
5\end{array}$ & 1 & $\begin{array}{l}0.03 \\
2\end{array}$ & 4 & 0.140 \\
\hline
\end{tabular}




\begin{tabular}{|c|c|c|c|c|c|c|c|c|c|}
\hline \multirow{2}{*}{ SWOT } & \multirow{2}{*}{$\begin{array}{l}\text { Weig } \\
\text { hted } \\
\text { points }\end{array}$} & \multicolumn{2}{|c|}{ SO } & \multicolumn{2}{|c|}{ ST } & \multicolumn{2}{|c|}{ WO } & \multicolumn{2}{|l|}{ WT } \\
\hline & & $\begin{array}{l}\text { A } \\
\text { S }\end{array}$ & TS & $\begin{array}{l}\text { A } \\
S\end{array}$ & $\mathrm{TS}$ & $\mathrm{AS}$ & $\mathrm{TS}$ & AS & TS \\
\hline $\begin{array}{l}\text { Existence of economic crises in the body } \\
\text { of urban and rural communities and } \\
\text { industrial areas in the region }\end{array}$ & $\begin{array}{l}0,023 \\
7\end{array}$ & 2 & $\begin{array}{l}0.06 \\
3\end{array}$ & 4 & $\begin{array}{l}0.12 \\
6\end{array}$ & 2 & $\begin{array}{l}0.06 \\
3\end{array}$ & 4 & 0.095 \\
\hline $\begin{array}{l}\text { Existence of weak cooperation of } \\
\text { governmental and non-governmental } \\
\text { organizations and bodies in waste } \\
\text { management affairs }\end{array}$ & $\begin{array}{l}0.035 \\
8\end{array}$ & 4 & $\begin{array}{l}0.08 \\
2\end{array}$ & 2 & $\begin{array}{l}0.04 \\
1\end{array}$ & 3 & $\begin{array}{l}0.06 \\
1\end{array}$ & 4 & 0.143 \\
\hline Instability of decisions at the macro level & $\begin{array}{l}0.019 \\
4\end{array}$ & 1 & $\begin{array}{l}0.03 \\
1\end{array}$ & 3 & $\begin{array}{l}0.09 \\
3\end{array}$ & 1 & $\begin{array}{l}0.03 \\
1\end{array}$ & 5 & 0.097 \\
\hline $\begin{array}{l}\text { Dispersal of decision centers in waste } \\
\text { management }\end{array}$ & $\begin{array}{l}0.024 \\
0\end{array}$ & 2 & $\begin{array}{l}0,03 \\
4\end{array}$ & 1 & $\begin{array}{l}0.01 \\
7\end{array}$ & 1 & $\begin{array}{l}0.01 \\
7\end{array}$ & 2 & 0.048 \\
\hline $\begin{array}{l}\text { Existence of weak cooperation of } \\
\text { relevant local departments in waste } \\
\text { management training, especially in small } \\
\text { towns and villages in the province }\end{array}$ & $\begin{array}{l}0,029 \\
2\end{array}$ & 1 & $\begin{array}{l}0,02 \\
1\end{array}$ & 1 & $\begin{array}{l}0,02 \\
1\end{array}$ & 1 & $\begin{array}{l}0,02 \\
1\end{array}$ & 4 & 0.117 \\
\hline Total & $\begin{array}{l}1 \\
0000\end{array}$ & 4 & $\begin{array}{l}4,99 \\
4\end{array}$ & 4 & $\begin{array}{l}2.76 \\
0\end{array}$ & 2 & $\begin{array}{l}1,57 \\
5\end{array}$ & & 3.372 \\
\hline
\end{tabular}

\section{Discussion}

The main objectives of this study are to study and understand the current situation in the field of waste management in Khorasan Razavi and also to provide an optimal management model that can help the urban management in order to achieve sustainable development . The analyzes used in this study yielded strategies to achieve the mentioned goals. Strategy based on strengthopportunity (offensive) was achieved with the first priority and strategy based on weaknessthreat (defensive) gained the second priority, therefore, different strategies were mentioned in line with the mentioned strategies and mentioning their importance.

Things like; increasing private sector participation, developing segregation programs from the source, developing recycling industries in the province and increasing the level of participation of managers and urban responsibility are such strategies which has been the result of a comprehensive study of the internal and external situation of the waste management system in the province.

Like many studies in the country that require first-hand statistical information s this study also faced many problems in obtaining these statistics and information, also, the multiplicity of decision-making centers and existing programs provided some parallel and sometimes contradictory information, which spent a lot of time verifying and prioritizing this information. 
In general, based on the findings of the present study, it can be said that the following suggestions can be made:

- Improving waste management frameworks and infrastructures throughout the study area.

- Develop precise rules and monitoring systems to implement the findings of scientific studies.

- Using the experience of other countries in the field of waste management.

- Turn waste management into an opportunity for revenue generation, not cost-orientation.

- Benefiting from people's participation in waste management.

\section{Conclusion}

Waste planning based on strategic and futuristic studies in the field of urban environment is one of the important developments that has attracted the attention of many experts on urban issues in various fields in recent years. As a result of such attention, various concepts and methods were developed to explain the position of urban waste indicators in the field of urban and regional management which by referring to these concepts, it can be seen that achieving the correct pattern of improving the quality of human spaces in relation to natural and manmade elements, it depends on the precise connection of new theoretical approaches with modern frameworks for planning and utilizing software models. Therefore, the present study has tried to accept the position of waste management as an important part of the process of achieving sustainable urban and regional development in the field of spatial studies, to seriously examine the various dimensions of the issue using a strategic approach along with meta-structural analysis. Therefore, in the framework of the conclusion, appropriate proposals are presented to strengthen and improve the stability of the waste management system in the study area.

\section{References}

Abdoli, M. (2012). Rural Waste Management, Municipalities and Villages Organization of the Ministry of Interior, SAMT Publisher.

Abdoli, M. (2012). Rural Waste Management in the Villages of Bushehr Province. Journal of Urban Management, 32, 89-95.

Abdoli, M. A. (2012). Rural Waste Management, Sixth National Conference and First International Conference on Waste Management, Mashhad.

Abdoli, M. A., Haghollahi, S. (2011). Characteristics of Rural Waste Processing and Recycling, Environmental Science, Thirty-seventh Year, No. 57.

Asadi, I. (2012). An analysis of the waste management system in the villages of Hamadan city, the sixth national conference on waste management.

Annual reports of the Environment Organization. (2015). Waste crisis in Iran's metropolises. Iran Environment Organization. 
Center for the Study of Municipalities of the Country. (2015). Waste plans and centralized urban management. Municipalities Publishing Center. First year, first issue.

Governor of Khorasan Razavi. (2016). Annual report on urban and rural waste. Rural Planning Commission.

Governor of Khorasan Razavi. (2016). Environment and municipal waste management. Internet portal.

Land management plan of Khorasan Razavi province. (2011). Comprehensive studies of the province. Mashhad University Jihad.

Mashhad Municipality. (2016). Municipal waste management. Annual Report of the Center for Urban Studies.

Mashhad Municipality Waste Management. (2016). Annual report of the center. may.

Natural Resources Organization of Khorasan Razavi Province. (2015). Natural areas of the province. Organization website. (www.razavi-agri-eng.ir).

Papli Yazdi, M. H. (2001). Technical and economic justification studies for urban waste recycling in Khorasan region, Civil Planning Office of the Ministry of Interior, Amir Kabir Research Institute.

Plan of Khorasan Razavi. (2011). Urban and Rural Settlements. Statistics and Practical Results, Chapter Three. Pp. 135-1.

Poor Alaghbandan, H. R., and Shahsavari, A. (2010). Municipal Solid Waste Engineering, Tehran: Publications of the Organization of Municipalities and Rural Affairs.

Rahnama, Mohammad Rahim. Aghajani, Hussein (2011). "Planning studies of Khorasan Razavi province". University Jihad Publications, Urban Planning Research Group, First Edition. 100- 1.

Statistics Center of Iran. (2015). Analytical report of Khorasan Razavi province. Internet portal (www.amar.org).

Statistics Center of Iran (2016). "Khorasan Razavi". Website of the National Statistics Center.

Tarhami, Z. (2010). Waste Management Master Plan Studies: Challenges and bottlenecks, Fifth National Conference on Waste Management.

Taqvaee, M. (2012). Urban Solid Waste Management, a Step Towards Sustainable Development, Case Study: Zanjan, Isfahan Urban Studies and Research Center, Third Year, No. 12.

Vosoughi, F. (2013). Investigating the behavior of Mashhad citizens towards environmental issues in Mashhad. Shahrpajooh Quarterly, 8, 289-297.

Vosoughi, F. (2003). Social Survey of Informal Occupations in Urban Waste Collection in Khorasan Province. Quarterly Journal of Geographical Research, 71, 185-193. 
Vosoughi, F. (2008). Organizing Solid Waste Recycling Industries in Mashhad (Necessity of Creating a Recycling Town). Journal of Zahedan University, 6(2), 57-66 .

Vosoughi, F. (2010-2011). Waste Management Plan and Population Centers in the Suburbs of Mashhad, Khorasan Razavi Governorate, Rural Affairs Office - Shargh Planning and Development Consulting Company.

Vosoughi, F., and Khazaei, S. (2011). Waste management in tourist areas - Example of Shandiz city, the first international conference and the sixth national conference on waste management. 